\title{
Erratum to: 'Neutrophil CD64 expression as a diagnostic marker for sepsis in adult patients: a meta-analysis'
}

\author{
Xiao Wang ${ }^{1}$, Zhong-Yun Li ${ }^{2}$, Ling Zeng ${ }^{1}$, An-Qiang Zhang ${ }^{3}$, Wei Pan', Wei Gu* and Jian-Xin Jiang ${ }^{1 *}$
}

Unfortunately, the original version of this article [1] contained an error. A sentence in the statistical analysis section was written incorrectly. It was written wrongly as:

"If there was significant heterogeneity, we choose a fixed model; if there was no heterogeneity, we choose a random model."

The correct form of this sentence is:

"If there was significant heterogeneity, we choose a random model; if there was no heterogeneity, we choose a fixed model."

\section{Author details}

${ }^{1}$ State Key Laboratory of Trauma, Burns and Combined Injury, Institute of

Surgery Research, Daping Hospital, Third Military Medical University,

Chongqing, China. ${ }^{2}$ The First Affiliated Hospital of Wenzhou Medical

University, Wenzhou, China. ${ }^{3}$ The 153 Central Hospital of PLA Jinan Military

Region, Zhengzhou, China.

Received: 9 May 2016 Accepted: 9 May 2016

Published online: 03 June 2016

\section{Reference}

1. Wang X, Li ZY, Zeng L, Zhang AQ, Pan W, Gu W, Jiang JX. Neutrophil CD64 expression as a diagnostic marker for sepsis in adult patients: a meta-analysis. Critical Care. 2015;19:245.

\footnotetext{
*Correspondence: clgwjm@163.com; hellojjx@126.com

'State Key Laboratory of Trauma, Burns and Combined Injury, Institute of Surgery Research, Daping Hospital, Third Military Medical University,

Submit your next manuscript to BioMed Central and we will help you at every step:

- We accept pre-submission inquiries

- Our selector tool helps you to find the most relevant journal

- We provide round the clock customer support

- Convenient online submission

- Thorough peer review

- Inclusion in PubMed and all major indexing services

- Maximum visibility for your research

Submit your manuscript at www.biomedcentral.com/submit 